\title{
Revisiting the hypothesis of sex-biased turtle road mortality
}

\author{
Sue Carstairs ${ }^{1}$, Marc Dupuis-Desormeaux ${ }^{2}$, and Christina M. Davy ${ }^{3,4}$, * \\ ${ }^{1}$ Ontario Turtle Conservation Centre, 4-1434 Chemong Road, Selwyn, Ontario K9J 6X2 Canada \\ ${ }^{2}$ York University, 4700 Keele Street, Toronto, Ontario M3J 1P3 Canada \\ ${ }^{3}$ Wildlife Research and Monitoring Section, Ontario Ministry of Natural Resources and Forestry, Trent University, 2140 East \\ Bank Drive, Peterborough, Ontario K9J 7B8 Canada \\ ${ }^{4}$ Environmental and Life Sciences Graduate Program, Trent University, Peterborough, Ontario K9J 7B8 Canada \\ *Corresponding author: christina.davy@ontario.ca
}

Carstairs, S., M. Dupuis-Desormeaux, and C.M. Davy. 2018. Revisiting the hypothesis of sex-biased turtle road mortality. Canadian Field-Naturalist 132(3): 289-295. https://doi.org/10.22621/cfn.v132i3.1908

\begin{abstract}
Road mortality poses a major threat to turtle populations. Several studies have suggested that the terrestrial movements associated with nesting increase this risk for females. The Ontario Turtle Conservation Centre (OTCC) is home to the Kawartha Turtle Trauma Centre, which admits 900 or more turtles a year, with road injuries the primary cause of admission. We tested the hypothesis that road mortality in turtles is female-biased using data from injured Midland Painted Turtles (Chrysemys picta marginata), Snapping Turtles (Chelydra serpentina), Blanding's Turtles (Emydoidea blandingii), and Northern Map Turtles (Graptemys geographica) collected over about $126000 \mathrm{~km}^{2}$ and admitted to OTCC's hospital from January 2013 to October 2017. There was no difference in the number of male and female admissions of Midland Painted, Blanding's, or Snapping Turtles $(P>0.05)$; however, more female Northern Map Turtles than males were admitted $(P<0.001)$. Admission of female turtles peaked in June during the nesting season, but male admissions were more evenly distributed throughout the season. Our admissions data provide a temporally unbiased and geographically broad snapshot of turtle-vehicle interactions that can directly inform conservation and management policies. Although our data are not equivalent to mortality rates, these results demonstrate that vehicle strikes can have a substantial impact on both female and male turtles.
\end{abstract}

Key words: Midland Painted Turtle; Snapping Turtle; Blanding’s Turtle; Northern Map Turtle; Chelydra serpentina; Chrysemys picta; Emydoidea blandingii; Graptemys geographica; Ontario; road ecology; road mortality; sex-biased dispersal; sex ratio; wildlife rehabilitation

\section{Introduction}

Roads have been called the "sleeping giant" of conservation biology (Forman and Alexander 1998) because of their pervasive negative impact on biodiversity and habitat connectivity. The effects of roads include habitat fragmentation, barriers to movement, genetic isolation of population fragments, and direct mortality from vehicle-wildlife collisions (Strasbourg 2006; van der Ree et al. 2011; Beebee 2013). Smaller, slower wildlife species may be more susceptible to vehicle strikes because they take more time to cross a road, increasing the probability of interaction with a vehicle, and may not use flight as a predator response, further increasing the likelihood of vehicle strikes (Fahrig and Rytwinski 2009). Turtles are particularly vulnerable to mortality caused by vehicle strikes because their long lifespan and slow population growth rates magnify the population-level impact of small increases in adult mortality (Congdon et al. 1993; Gibbs and Steen 2005; Crawford et al. 2014; Rytwinski and Fahrig 2015).

Several studies have tested the hypothesis that female turtles are at higher risk of road mortality during the nesting season because overland movements required to find a suitable nest site may increase females' probability of contact with roads (Steen and Gibbs 2004; Aresco 2005; Gibbs and Steen 2005; Steen et al. 2006; Patrick and Gibbs 2010; Dorland et al. 2014). In addi- tion, females that nest on the shoulder of paved roads, even those that have repeatedly nested at the same area, can spend considerable amounts of time searching the road, whereas males typically cross the road and do not show this nest-searching behaviour (R. Brooks pers. comm. 11 May 2018). If road mortality is female-biased, then the adult sex ratios of turtle populations should gradually become male-biased (Steen and Gibbs 2004; Gibbs and Steen 2005; Steen et al. 2006; Patrick and Gibbs 2010; Dupuis-Désormeaux et al. 2017).

Road mortality studies often do not report the sex of the turtles (e.g., Ashley and Robinson 1996; Gunson et al. 2014; Baxter-Gilbert et al. 2015; Coquette and Valliant 2016; Dupuis-Désormeaux et al. 2017) or only report the sex of a limited sample (Haxton 2000). In addition, some road mortality surveys are carried out for a limited portion of the active season (e.g., Haxton 2000 ) or for a limited number of days throughout the season (e.g., Cureton and Deaton 2012). A temporally unbiased dataset of road mortality occurrences in male and female turtles is required to test directly the hypothesis of sex-biased road mortality occurrences in turtles at the landscape scale.

The Ontario Turtle Conservation Centre (OTCC; https://ontarioturtle.ca/) is home to Canada's only dedicated turtle rehabilitation centre. The OTCC admits turtles injured in a variety of ways, but the vast majority 
of admissions (80-95\%, depending on the species) represent turtles injured on roads across southern Ontario. Southern Ontario contains 92\% of Ontario's human population and some of the highest concentrations of roads on the planet with a road located, on average, every $1.5 \mathrm{~km}$ (Gunson 2010; Laurance et al. 2014). Admissions to the OTCC include all eight species of turtles native to Ontario, including the globally endangered Spotted Turtle (Clemmys guttata; van Dijk 2011) and Blanding's Turtle (Emydoidea blandingii; van Dijk and Rhodin 2011). All Ontario species except Spiny Softshell (Apalone spinifera) have been admitted with vehicle-related injuries.

Admissions to the OTCC have increased steadily since 2010 (Figure 1), in part because of increased public participation following intensive public education initiatives. The OTCC admissions dataset provides an opportunity to test the hypothesis of sex-biased road effects on a large, temporally unbiased and geographically broad sample of turtles struck by vehicles across an area of approximately $126000 \mathrm{~km}^{2}$. We used OTCC data to test the hypothesis that interactions with vehicles affect more female turtles than males, predicting that if more females than males are struck by vehicles in our intake area, then counts of turtles admitted to the OTCC would also be significantly female biased.

\section{Methods}

Located in Peterborough, Ontario $\left(44.336776^{\circ} \mathrm{N}\right.$, $78.348319^{\circ} \mathrm{W}$ ), the OTCC is the home of the Kawartha

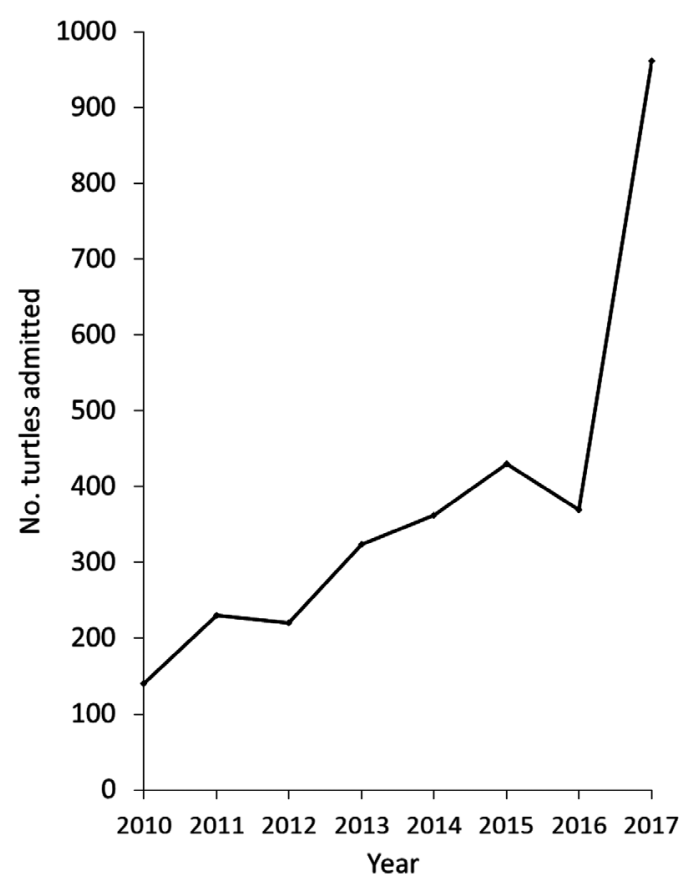

FIGURE 1. Increase in admissions to the turtle hospital at the Ontario Turtle Conservation Centre since 2010.
Turtle Trauma Centre (KTTC), which receives cases from across southern Ontario and occasionally from southern Quebec. Turtles are brought to the OTCC by members of the public and field biologists or transferred from other wildlife rehabilitation centres when complex veterinary care is required. Admissions include all species of turtles native to Ontario, but the majority are Midland Painted Turtles (Chrysemys picta marginata), Snapping Turtles (Chelydra serpentina), and Blanding's Turtles. During admission, OTCC staff record each turtle's species, sex, size (carapace length and width), and age class (hatchling, juvenile, or adult), as well as the reason for admission and the collection location. Admissions to the hospital take place all year round; however, most occur from mid-April to late October, during the active season of turtles in southern Ontario.

Vehicle strikes typically cause life-threatening injuries to turtles (Figure 2), and medical records from the centre confirm that successful outcomes and rehabilitation of turtles hit by vehicles depend on rapid veterinary treatment. Therefore, these turtles would have died in the absence of treatment, and their admissions data are an appropriate proxy for vehicle-related mortalities.

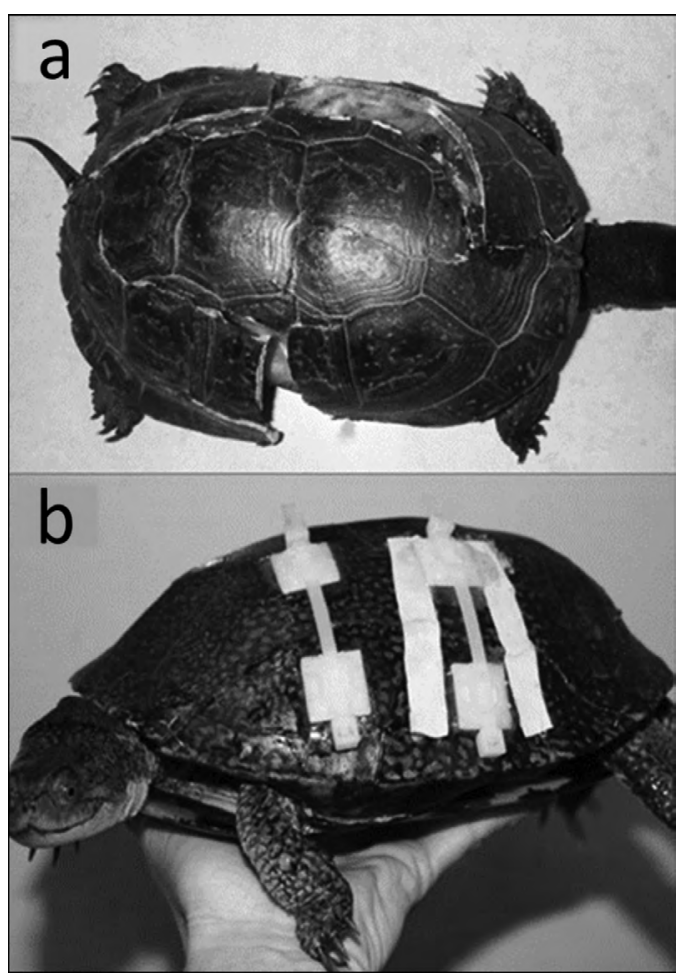

FigURE 2. a. Injuries from vehicle strikes are typically lifethreatening, as in this Blanding's Turtle (Emydoidea blandingii), but rapid surgical attention often allows turtles to recover. b. Blanding's Turtle that was successfully rehabilitated and released back into the wild. Photos: S. Carstairs. 
Successfully rehabilitated turtles are released back into the wild near their initial collection location.

We used OTCC admissions data from January 2013 to October 2017 to test whether vehicle strikes on turtles occur more frequently in one sex than the other. We removed the records of turtles that were admitted for other reasons and limited our data set to those hit by a vehicle. We tested for significant deviations from an unbiased sex ratio in the admissions data by performing a nonparametric binomial two-sided test based on a one-sample binomial distribution (Wilson and Hardy 2002) with the untested assumption that the populations of turtles in the study area were also not sex biased. All statistics were performed in Microsoft Excel (Microsoft Corporation, Redmond, Washington, USA), and we considered results significant at $\alpha=0.05$. Loca- tion data were mapped using ArcMap 10.1 (ESRI, Redlands, California, USA).

\section{Results}

During the study period, the OTCC admitted 2355 turtles, of which 2020 were admitted due to vehicle strikes (Figure 3). Of these, 1722 were mature individuals and were sexed during the admission process; Wood Turtle (Glyptemys insculpta) vehicle strikes are not shown due to locational sensitivity. Most vehicle strikes involved Midland Painted Turtles (62\%), followed by Snapping Turtles (29\%), and Blanding's Turtles $(6.5 \%$; Table 1$)$. Approximately half $(51 \%)$ of turtles admitted because of vehicle strikes were female, and admissions of female Midland Painted Turtles, Snapping Turtles, and Blanding's Turtles peaked in

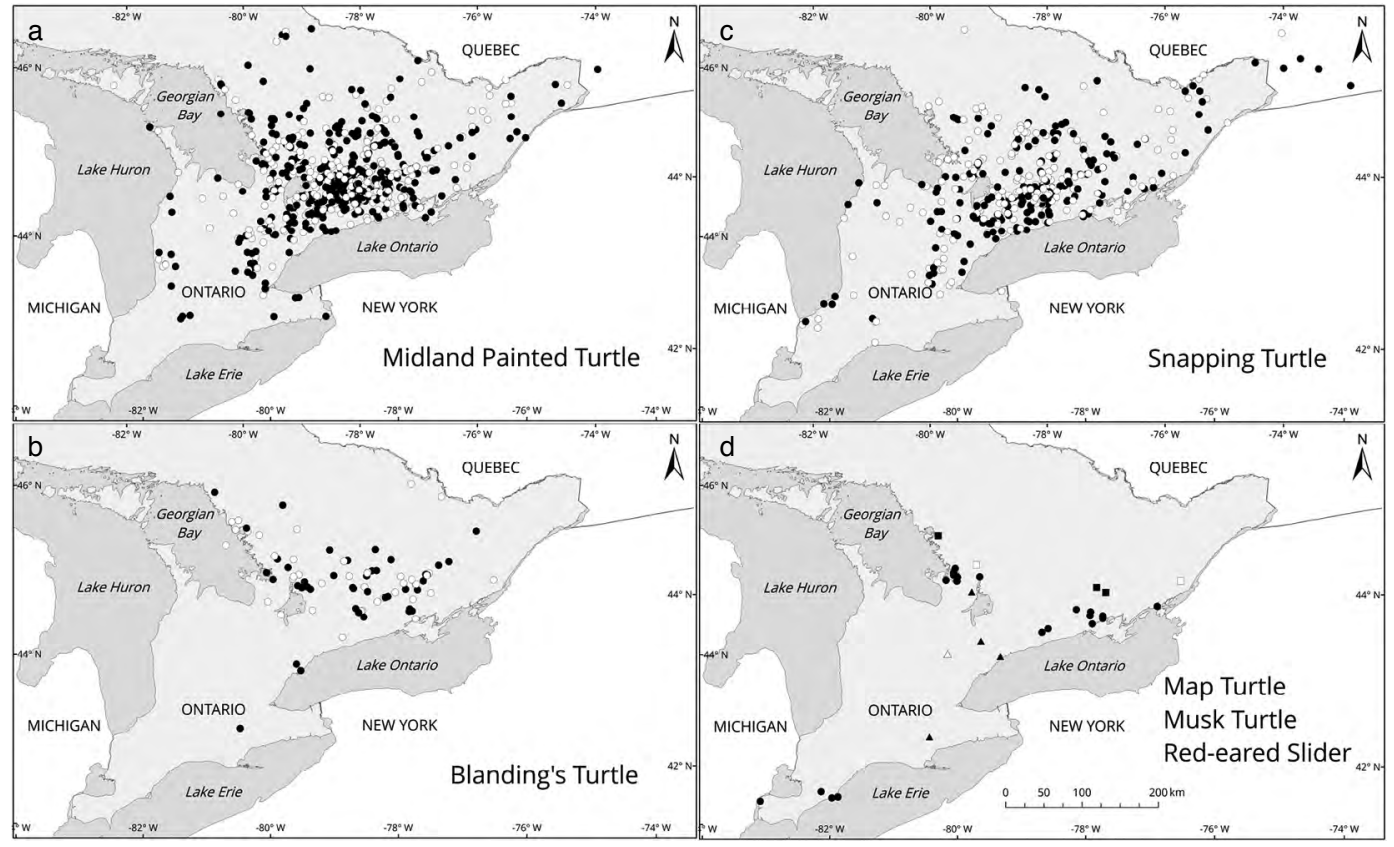

FIGURE 3. Locations of vehicle strikes of adult turtles admitted to the Ontario Turtle Conservation Centre, 2013-2017. Open symbols = males; black-filled symbols = females. In the lower right panel (d), circles indicate Northern Map Turtles (Graptemys geographica); squares indicate Eastern Musk Turtles (Sternotherus odoratus); and triangles indicate Red-eared Sliders (Trachemys scripta elegans).

TABLE 1. Species and sex distribution for 1722 adult turtles admitted to the Ontario Turtle Conservation Centre because of vehicular collisions from 2013 to 2017.

\begin{tabular}{lcccc}
\hline \hline Species & Females & Males & Proportion of males & $\boldsymbol{P}^{*}$ \\
\hline Painted Turtle (Chrysemys picta) & 541 & 532 & 0.496 & 0.404 \\
Snapping Turtle (Chelydra serpentina) & 249 & 254 & 0.505 & 0.606 \\
Blanding's Turtle (Emydoidea blandingii) & 63 & 49 & 0.438 & 0.120 \\
Northern Map Turtle (Graptemys geographica) & 32 & 2 & 0.059 & $<0.001^{\dagger}$ \\
Total & 885 & 837 & 0.486 & 0.129 \\
\hline \hline
\end{tabular}

*Indicates cumulative probability that the observed sex ratio reflects an unbiased binomial distribution centred around 0.5 .

${ }^{\dagger}$ Sample was significantly biased toward one sex or the other $(\alpha=0.05)$. 
June, concurrent with the nesting season for these species. Admissions of male turtles showed multiple clusters extending from early spring to late fall (Figure 4). Turtles were admitted for care following vehicle strikes as early as 13 March (2013), as late as 25 October (2017).

A binomial test showed that admissions of male and female turtles struck by vehicles, when combined over all five years, were not statistically different for Midland Painted Turtles $(P=0.404)$, Snapping Turtles $(P=$ $0.660)$, or Blanding's Turtles $(P=0.110$; Table 1$)$. Admissions of Northern Map Turtles (Graptemys geographica) were significantly female biased $(P<0.001)$, but map turtles made up only $2 \%$ of all vehicle-related admissions.

\section{Discussion}

Our temporally unbiased, 5-year admissions dataset from the OTCC does not support the hypothesis of sex-biased road mortality in Midland Painted, Snapping, or Blanding's Turtles, but suggests that roads may have a greater impact on female Northern Map Turtles than on males. The OTCC admits turtles year round, enabling continuous collection of road mortality data over five years and accurate sexing of each turtle admitted. Our road mortality data are count data, like those of most other road ecology studies, and cannot be converted to mortality rates because robust demographic data are available for only a few well-studied turtle populations. However, the even distribution of road mortality occurrences among males and females of the most commonly hit species in our dataset suggests that the impact of roads on turtles is more evenly shared between the two sexes than previous studies have suggested.

Painted, Snapping, and Blanding's turtles frequently move over land to find mates, to access resources such as foraging or overwintering sites, or to find a suitable nest site (Pettit et al. 1995; Tuberville et al. 1996; Ernst and Lovich 2009). These activities bring both males and females of these three species into contact with roads, as reflected in our data. Nesting season is clearly associated with increased risk of road injury for female turtles in Ontario. However, our results also provide empirical support to a recent modelling approach (Beaudry
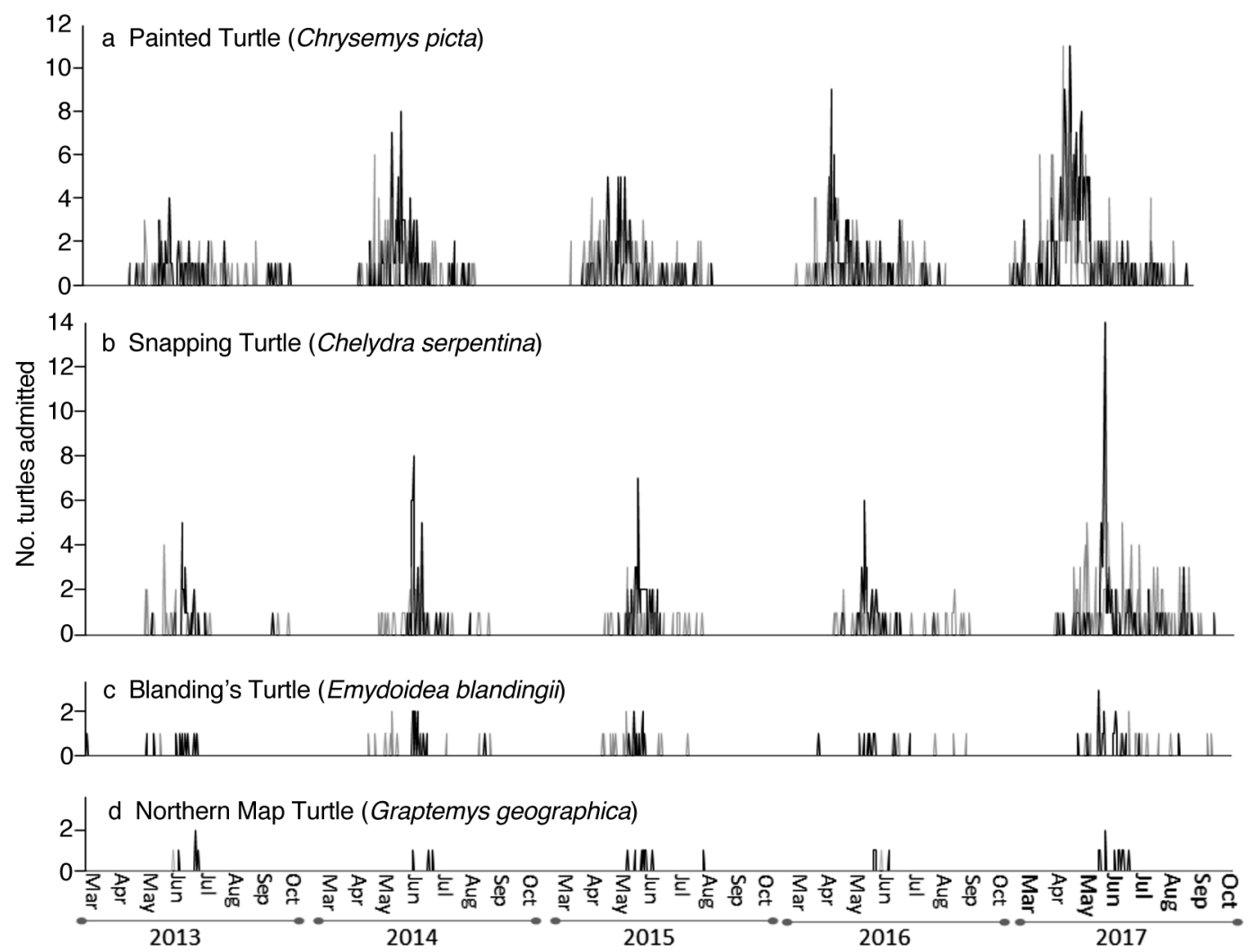

Figure 4. Admissions of male and female turtles struck by vehicles $(n=1722)$. Numbers are similar for male and female a. Midland Painted (Chrysemys picta), b. Snapping (Chelydra serpentina), and c. Blanding's Turtles (Emydoidea blandingii). Admissions of female turtles (black lines) peaked during the nesting season, while admissions of males (grey lines) were more evenly spread through the season. d. Northern Map Turtle (Graptemys geographica) females were more likely to be admitted than males. No admissions caused by vehicle strikes occurred from November to February. 
et al. 2010) that suggests that male mortality is similar to female mortality when the entire active season of mid-April to the end of October is considered. Beaudry et al. (2010) found that male and female Blanding's Turtles had similarly long movement patterns and were both similarly exposed to road mortality. However, males moved more than females, before and after nesting season.

Although our sample of Northern Map Turtles was small $(n=34)$, it was heavily biased toward females (94\%). The behaviour of Northern Map Turtles is consistent with this observation: male Northern Map Turtles are almost exclusively aquatic, whereas females emerge rarely, usually only to find a suitable nest site (Ernst and Lovich 2009).

Survivorship in female turtles has been a focus of turtle ecologists and conservation biologists for good reason; it has an extremely high impact on the growth rates of turtle populations (Congdon et al. 1993; Heppell et al. 1996; Heppell 1998; Mitrus 2005; Enneson and Litzgus 2008). Therefore, maximizing female survivorship is considered a key component of effective turtle conservation. Nevertheless, reproductive males and females are required to sustain a viable turtle population, and conservation programs should ensure adequate survival rates in both sexes. Most methods used to mitigate road impacts on turtles (ecopassages, drift fencing, etc.) probably provide equal protection to both sexes. Road closures during the nesting season may adequately protect nesting female turtles but fail to protect males and females moving overland during the rest of the active season.

One tool used to recover threatened turtle populations is "headstarting", in which eggs are hatched in artificial conditions that maximize success and eliminate nest depredation. Hatchlings are often also reared for some amount of time before release, which may reduce the risk of early juvenile mortality (e.g., Iverson 1990; Haskell 1996; Bennett et al. 2017). In species with temperature-dependent sex determination, incubation conditions can be controlled to produce a predetermined sex ratio in hatchlings. Setting aside the many factors that can prevent recruitment of headstarted or wild-hatched juveniles to a turtle population, our data add evidence to suggest that headstarting projects or other attempts to augment populations should consider both sexes and not focus solely on females. The fact that females spend more time on roads, and yet males are struck in equal numbers, also illustrates the high impact of roads on the male population.

Converting mortality count data, such as those presented here, to mortality rates for male and female turtles in a population and, thus, inferring and projecting population level impacts requires knowledge of the sex ratio of the underlying population - a major limitation of our study and of many others. Accurately estimating population sex ratios requires substantial survey effort, and some survey methods do not have equal detection rates for both sexes. For example, hoop traps may capture male-biased samples of Painted Turtle populations (Ream and Ream 1966), while surveys of turtle nesting sites are necessarily female-biased. Furthermore, counts of road mortality for long-lived animals, such as turtles, do not accurately represent demographic trends (Rytwinski and Fahrig 2015), and unequal male and female road mortality rates could cause yearly fluctuations in the population's sex ratio as the population nears extinction.

The underlying reasons for the discrepancy between the equal sex ratio in road injuries that we found and the increasing male-biased population sex ratios correlated with higher road densities found in numerous other studies (e.g., Marchand and Litvaitis 2004; Steen and Gibbs 2004; Aresco 2005; Gibbs and Steen 2005; Steen et al. 2006; Patrick and Gibbs 2010) remain uncertain. We urge road ecologists to remain critical of the underlying assumptions in the interpretation of mortality counts, and we urge turtle researchers to be cautious of assumptions that could inadvertently prioritize protection of one sex over the other.

The morbidity and mortality of reptiles admitted to wildlife care facilities in North America has been described previously (Hartup 1996; Brown and Sleeman 2002; Rivas et al. 2014), but these studies focus on the veterinary medicine aspects of rehabilitation. Our study demonstrates how admission data from a wildlife rehabilitation centre can be used to address broader questions in conservation and draw inferences about threats to wild populations. Perhaps a future approach to these and new data would be to examine the sex ratio variation with location and to compare traffic, road density, or population composition. There are numerous possibilities, but our large sample at a landscape level is unique and could be explored further. Turtles are longlived and slow to mature and the survival rate of eggs and hatchlings is low. Turtle populations cannot recover quickly from increased adult mortality (Brooks et al. 1991). Conversely, offsetting increased mortality can have a relatively large impact on demographic rates, such that rehabilitation and release of injured turtles may have a population-level effect.

\section{Acknowledgements}

We thank Lindsay Maxim, Donnell Gasbarrini, and all the staff and volunteers at the Ontario Turtle Conservation Centre who admitted, cared for, and released the turtles described in this study. Thanks also to Lucy Brown for preparing Figure 3. The Ontario Turtle Conservation Centre is accredited as a wildlife rehabilitation centre by the Government of Ontario. We thank the many generous individuals and organizations who support the centre, including the Ontario Ministry of Natural Resources and Forestry. R. Brooks (professor emeritus, Department of Integrative Biology, College of Biological Science, University of Guelph) provided information from his many years observing wild turtles. 


\section{Literature Cited}

Aresco, M.J. 2005. The effect of sex-specific terrestrial movements and roads on the sex ratio of freshwater turtles. Biological Conservation 123: 37-44. https://doi.org/10.1016/j. biocon.2004.10.006

Ashley, P.A., and J.T. Robinson. 1996. Road mortality of amphibians, reptiles and other wildlife on the Long Point Causeway, Lake Erie, Ontario. Canadian Field-Naturalist 110: 403-412. Accessed 6 July 2018. https://biodiversityli brary.org/page/34343309.

Baxter-Gilbert, J.H., J.L. Riley, D. Lesbarrères, and J.D. Litzgus. 2015. Mitigating reptile road mortality: fence failures compromise ecopassage effectiveness. PLoS ONE 10: e0120537. https://doi.org/10.1371/journal.pone.0120537

Beaudry, F., P.G. Demaynadier, and M.L. Hunter, Jr. 2010. Identifying hot moments in road-mortality risk for freshwater turtles. Journal of Wildlife Management 74: 152-159. https://doi.org/10.2193/2008-370

Beebee, T.J. 2013. Effects of road mortality and mitigation measures on amphibian populations. Conservation Biology 27: 657-668. https://doi.org/10.1111/cobi.12063

Bennett, A., J. Steiner, S. Carstairs, A. Gielens, and C. Davy. 2017. A question of scale: replication and the effective evaluation of conservation interventions. FACETS 2: 892-909. https://doi.org/10.1139/facets-2017-0010

Brooks, R.J., G.P Brown, and D.A. Galbraith. 1991. Effects of a sudden increase in natural mortality of adults on a population of the common snapping turtle (Chelydra serpentina). Canadian Journal of Zoology 69: 1314-1320. https://doi.org/10.1139/z91-185

Brown, J.D., and J.M. Sleeman. 2002. Morbidity and mortality of reptiles admitted to the Wildlife Center of Virginia, 1991 to 2000. Journal of Wildlife Diseases 38: 699-705. https://doi.org/10.7589/0090-3558-38.4.699

Congdon, J.D., A.E. Dunham, and R.C. van Loben Sels. 1993. Delayed sexual maturity and demographics of Blanding's turtles (Emydoidea blandingii): implications for conservation and management of long-lived organism. Conservation Biology 7: 826-833. https://doi.org/10.1046/j.15 23-1739.1993.740826.x

Coquette, J.D., and L. Vaillant. 2016. Road mortality of reptiles and other wildlife at Ojibway Prairie Complex and Greater Park Ecosystems in southern Ontario. Canadian Field-Naturalist 130: 64-75. https://doi.org/10.22621/cfn. v130i1.1804

Crawford, B.A., J.C. Maerz, N.P. Nibbelink, K.A. Buhlmann, and T.M. Norton. 2014. Estimating the consequences of multiple threats and management strategies for semi-aquatic turtles. Journal of Applied Ecology 51: 359366. https://doi.org/10.1111/1365-2664.12194

Cureton, J.C., and R. Deaton. 2012. Hot moments and hot spots: identifying factors explaining temporal and spatial variation in turtle road mortality. Journal of Wildlife Management 76: 1047-1052. https://doi.org/10.1002/jwmg.320

Dorland, A., T. Rytwinski, and L. Fahrig. 2014. Do roads reduce painted turtle (Chrysemys picta) populations? PLoS ONE 9: e98414. https://doi.org/10.1371/journal. pone.0098414

Dupuis-Désormeaux, M., V. D'Elia, C. Cook, J. Pearson, V. Adhikari, and S. MacDonald. 2017. Remarkable male bias in a population of Midland Painted Turtles (Chrysemys picta marginata), in Ontario, Canada. Herpetological Conservation and Biology 12: 225-232.

Enneson, J.J., and J.D. Litzgus. 2008. Using long-term data and a stage-classified matrix to assess conservation strate- gies for an endangered turtle (Clemmys guttata). Biological Conservation 141: 1560-1568. https://doi.org/10.1016/j.bio con.2008.04.001

Ernst, C.H., and J.E. Lovich. 2009. Turtles of the United States and Canada. Second Edition. John Hopkins University Press, Baltimore, Maryland, USA.

Fahrig, L., and T. Rytwinski. 2009. Effects of roads on animal abundance: an empirical review and synthesis. Ecology and Society 14: 21.

Forman, R.T., and L.E. Alexander. 1998. Roads and their major ecological effects. Annual Review of Ecology and Systematics 29: 207-231. https://doi.org/10.1146/annurev. ecolsys.29.1.207

Gibbs, J.P., and D.A. Steen. 2005. Trends in sex ratios of turtles in the United States: implications of road mortality. Conservation Biology 19: 552-556. https://doi.org/10.1111/ j.1523-1739.2005.000155.x

Gunson, K.E. 2010. Green infrastructure design for municipal roads. Municipal World 120: 9-10.

Gunson, K., E. Lesbarreres, and D. Seburn. 2014. Monitoring turtle movement on highways 7 and 41, Ontario (unpublished report). Ontario Ministry of Transportation, Toronto, Ontario, Canada.

Hartup, B.K. 1996. Rehabilitation of native reptiles and amphibians in DuPage County, Illinois. Journal of Wildlife Diseases 32: 109-112. https://doi.org/10.7589/0090-355832.1.109

Haskell, T.E. 1996. Size-related survival of headstarted redbelly turtles (Pseudemys rubriventris) in Massachusetts. Journal of Herpetology 30: 524-527. https://doi.org/10. $2307 / 1565695$

Haxton, T. 2000. Road mortality of Snapping Turtles, Chelydra serpentina, in central Ontario during their nesting period. Canadian Field-Naturalist 114: 106-110. Accessed 23 February 2019. https://biodiversitylibrary.org/page/3423 6602.

Heppell, S.S. 1998. Applications of life-history theory and population model analysis to turtle conservation. Copeia 1998: 367-375. https://doi.org/10.2307/1447430

Heppell, S.S., L.B. Crowder, and D.T. Crouse. 1996. Models to evaluate headstarting as a management tool for longlived turtles. Ecological Applications 6: 556-565. https:// doi.org/10.2307/2269391

Iverson, J.B. 1990. Patterns of survivorship in turtles (order Testudines). Canadian Journal of Zoology 69: 385-391. https://doi.org/10.1139/z91-060

Laurance, W.F., G.R. Clements, S. Sloan, C.S. O'Connell, N.D. Muelle, M. Goosem, O. Venter, D.P. Edwards, B. Phalan, A. Balmford, and R. Van Der Ree. 2014. A global strategy for road building. Nature 513: 229-232. https:// doi.org/10.1038/nature13717

Marchand, M.N., and J.A. Litvaitis. 2004. Effects of habitat features and landscape composition on the population structure of a common aquatic turtle in a region undergoing rapid development. Conservation Biology 18: 758-767. https:// doi.org/10.1111/j.1523-1739.2004.00019.x

Mitrus, S. 2005. Headstarting in European pond turtles (Emys orbicularis): does it work? Amphibia-Reptilia 26: 333-341. https://doi.org/10.1163/156853805774408504

Patrick, D.A., and J.P. Gibbs. 2010. Population structure and movements of freshwater turtles across a road-density gradient. Landscape Ecology 25: 791-801. https://doi.org/10. 1007/s10980-010-9459-0

Pettit, K.E., C.A. Bishop, and R.J. Brooks. 1995. Homerange and movements of the Common Snapping Turtle, 
Chelydra serpentina serpentina, in a coastal wetland of Hamilton Harbour, Lake Ontario, Canada. Canadian FieldNaturalist 109: 192-200. Accessed 23 February 2019. https://biodiversitylibrary.org/page/35457040.

Ream, C., and R. Ream. 1966. The influence of sampling methods on the estimation of population structure in painted turtles. American Midland Naturalist 75: 325-338. https:// doi.org/10.2307/2423395

Rivas, A.E., M.C. Allender, M. Mitchell, and J.K. Whittington. 2014. Morbidity and mortality in reptiles presented to a wildlife care facility in Central Illinois. Human-Wildlife Interactions 8: 78-87.

Rytwinski, T., and L. Fahrig. 2015. The impacts of roads and traffic on terrestrial animal populations. Pages 237-246 in Handbook of Road Ecology. First Edition. Edited by R. van der Ree, D.J. Smith, and C. Grilo. John Wiley \& Sons, Ltd., Chichester, United Kingdom.

Steen, D.A., M.J. Aresco, S.G. Beilke, B.W. Compton, E.P. Condon, C.K. Dodd, Jr., H. Forrester, J.W. Gibbons, J.L. Greene, G. Johnson, T.A. Langen, M.J. Oldham, D.N. Oxier, R.A. Saumure, F.W. Schueler, J.M. Sleeman, L.L. Smith, J.K. Tucker, and J.P. Gibbs. 2006. Relative vulnerability of female turtles to road mortality. Animal Conservation 9: 269-273. https://doi.org/10.1111/j.14691795.2006.00032.x

Steen, D.A., and J.P. Gibbs. 2004. Effects of roads on the structure of freshwater turtle populations. Conservation Biology 18: 1143-1148. https:/doi.org/10.1111/j.1523-17 39.2004.00240.x
Strasburg, J.L. 2006. Conservation biology: roads and genetic connectivity. Nature 440: 875-876. https://doi.org/10. 1038/440875a

Tuberville, T.D., J.W. Gibbons, and J.L. Greene. 1996. Invasion of new aquatic habitats by male freshwater turtles. Copeia 1996: 713-715. https://doi.org/10.2307/1447536

van der Ree, R., J.A. Jaeger, E.A. van der Grift, and A.P. Clevenger. 2011. Effects of roads and traffic on wildlife populations and landscape function: road ecology is moving toward larger scales. Ecology and Society 16: 48.

van Dijk, P.P. 2011. Clemmys guttata (errata version published in 2016). In The IUCN Red List of Threatened Species: e.T4968A97411228. https://doi.org/10.2305/IUCN. UK.2011-1.RLTS.T4968A11103766.en

van Dijk, P.P., and A.G.J. Rhodin. 2011. Emydoidea blandingii (errata version published in 2017). In The IUCN Red List of Threatened Species: e.T7709A121707136. Accessed March 17 2019. https://www.iucnredlist.org/species/7709/ 121707136.

Wilson, K., and I.C.W. Hardy. 2002. Statistical analysis of sex ratios: an introduction. Pages 53-55 in Sex Ratios: Concepts and Research Methods. Edited by I.C.W. Hardy. Cambridge University Press, New York, New York, USA. https://doi.org/10.1017/CBO9780511542053.004

Received 10 February 2017

Accepted 6 July 2018 